\title{
<症例報告 $>$
}

\section{尿管癌から生じた腫瘍性動脈瘤によるくも膜下出血の 1 例}

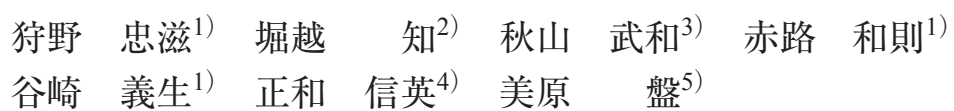

要旨：症例は 86 歳, 男性. 既往として尿管癌を指摘されていたが, 積極的な治療は受 けていなかった. 突然の左片麻瘏を契機として当院に救急搬送された. 来院時の頭部 CT にて，右前頭葉に皮質下出血を認めた。頭部 MRA では明らかな異常血管は認めなかった. 保存的に加療を行い, 回復期リハビリテーション病棟へ転床となった。発症 31 病日に, 突 然の頭痛を訴えた。頭部 CT にて左円蓋部にくも膜下出血を認め, 頭部 MRA と脳血管撮影 にて左中大脳動脈末梢に紡錐状動脈瘤の新生を認めた。開頭動脈瘤トラッピング術ならび に切除術を施行した。病理検査にて動脈瘤壁に異型細胞の浸潤増殖を認め腫瘍性動脈瘤と 診断された。術後は, トラッピングに伴う脳梗塞を発症せず経過し, リハビリテーション を継続した，担癌状態の患者に生じた動脈瘤に於いては，腫瘍性動脈瘤の可能性を考慮し て治療にのぞむ必要があると考えられた。

Key words: neoplastic aneurysm, subarachnoid hemorrhage, urotherial carcinoma

(脳卒中 34: 29-33, 2012)

\section{はじめに}

腫瘍の脳転移に伴って生じる腫瘍性脳動脈瘤は稀 であり, 心臟粘液腫や絨毛癌からの転移による動脈 瘤の報告が散見される ${ }^{1-13)}$ 。また, 肺癌の転移に伴 う腫瘍性脳動脈瘤も僅かに報告されている ${ }^{14-18)}$ 。 ま とまった症例数の報告はなく, 動脈瘤の形成過程や 破裂までの経過に関しては不明な点が多い.今回, 我々は約 1 カ月の経過で瘤を生じ, 破裂に至った尿 管癌由来の腫瘍性動脈瘤の 1 例を経験したので報告 する.

\section{症例}

患者：86 歳, 男性

主訴：左半身の脱力

家族歴：特記事項なし

1) 美原記念病院脳神経外科

2) 美原記念病院脳卒中部門

3) 秋山脑神経外科内科病院脳神経外科

4)獨協医科大学病理学 (形態)

5) 美原記念病院神経内科

（2011 年 9 月 28 日受付， 2011 年 10 月 12 日受理）
既往歴：2011 年 3 月から尿管癌を指摘されていた が, 本人希望にて未治療であった。

現病歴：2011 年 5 月 9 日昼ごろから, 左半身の脱 力を自覚していた. 夜間になっても改善を認めない ために当院に救急搬送され入院となった.

入院時現症：身長 $160 \mathrm{~cm}$, 体重 $50.5 \mathrm{~kg}$, 血圧 159/75 mmHg, 脈拍 96 回/ 分, 体温 36.3 度, 胸腹部 一般身体所見に異常なし，神経学的にはJCSI-1，左 上下肢に不全片麻痺 (徒手筋力テスト4)。感覚障害 は認めず，深部腱反射は左側で軽度光進，病的反射 は認めなかった。

検查所見：検尿にて潜血が $3+$ であった。血液検査 は末梢血にて赤血球 $371 \times 10^{4} / \mathrm{mm}^{3}, \mathrm{Hb} 12.3 \mathrm{~g} / \mathrm{dl}, \mathrm{Ht}$ $36.8 \%$ と軽度の正球性貧血を認めた。白血球, 血小 板は正常であった. 生化学検査にて Alb $3.5 \mathrm{~g} / \mathrm{dl}$ と低 值であったが, 腎機能, 肝機能, 電解質は正常であっ た. 凝固検査にて FNG $607 \mathrm{mg} / \mathrm{d} 1$ と上昇していたが, PT, APTT は正常であった. 腫瘍マーカーは尿路上 皮癌に特異的な NMP -22 が $28.6 \mathrm{U} / \mathrm{ml}$ と上昇してい た. 胸部レントゲンでは肺野に転移を疑う, 多発結 節影を認めた。 心電図は正常で, 経胸壁心エコーの 所見も正常の範囲内であった. 


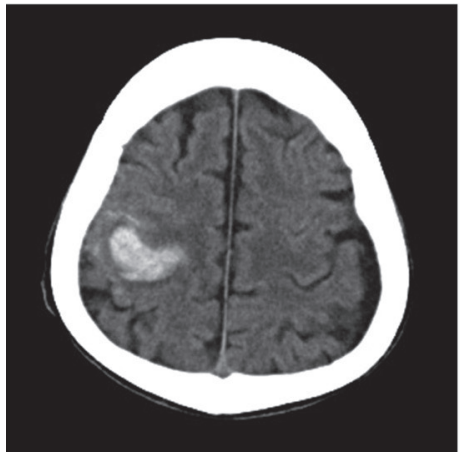

$\mathrm{A}$ : 頭部 CT

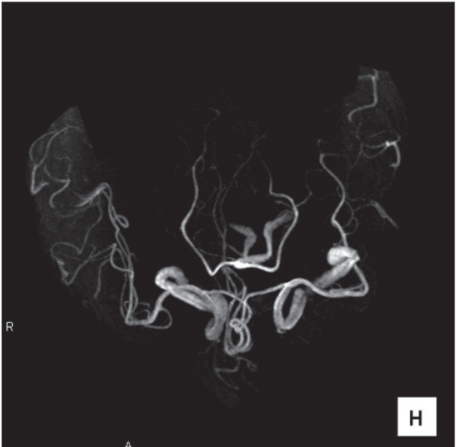

Fig. 1 入院時画像所見

右頭頂葉に皮質下出血を認める.

$B$ : 頭部 MRA

明らかな血管異常は認めない

$\mathrm{C}$ ：頭部 MRI T2*

低信号病変の多発は認めていない
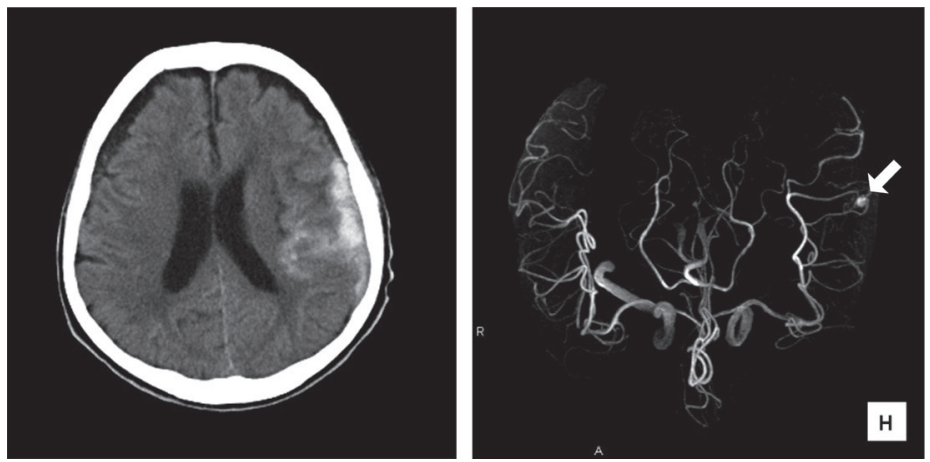

Fig. 2 <膜下出血発症時画像所見 $\mathrm{A}$ ：頭部 CT

左円蓋部にくも膜下出血を認める.

$\mathrm{B}$ : 頭部 MRA

左前頭頂動脈に紡錐状動脈瘤の新生を認める(矢印).

$\mathrm{C}$ : 脳血管撮影側面像

左前頭頂動脈に紡錐状動脈瘤の新生を認める(矢印).

画像所見：頭部 CT（Fig. 1A）にて右前頭葉に皮質 下出血を認めた．頭部 MRI では出血巣以外に，脳転 移を疑う浮腫などは認めず，頭部 MRA（Fig. 1B）で も明らかな血管異常は認めなかった. 頭部 MRI T2* 画像 (Fig. 1C) では, 低信号病変の多発所見は認め なかった。

経過：頭部 MRI T2*画像では典型的な所見は認め なかったものの，アミロイドアンギオパチーに伴う皮 質下出血と診断し, 保存的に加療を施行した. 左上
肢麻痺の進行を認めたものの，出血の増大なく回復 期リハビリテーション病棟に転床となった。 6 月 8 日 (発症 31 日目), トイレにて排泄後から強度の頭痛を 訴えた．頭部 CT（Fig. 2A）を施行したところ，左円蓋 部にくも膜下出血を認めた。頭部 MRA（Fig. 2B）では 左中大脳動脈の分枝である, 左前頭頂動脈に紡錐状 動脈瘤の新生を認めた。引き続き施行した脳血管撮 影(Fig. 2C)では，MRA と同様に左前頭頂動脈に動脈 瘤を認めたが, その他の血管には異常を認めなかっ 

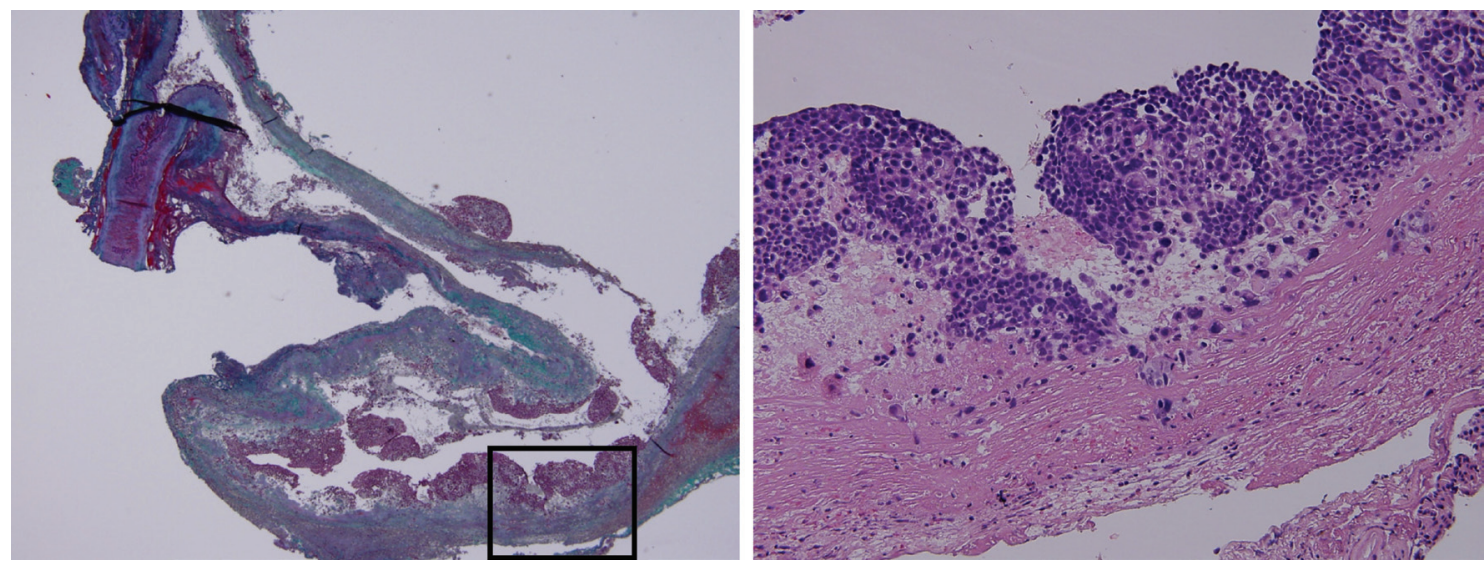

Fig. 3 病理検査所見

A : Elastica-Masson 染色

40 倍. 動脈壁はごく一部保存されるがほとんどは内弾性板の消失を含め, 菲薄化かつ消失している.

B : Hematoxilin-Eosin 染色

200 倍. 動脈壁の内側に小型の N/C 比の高い異形細胞が密に浸潤増殖をしている.

結合様式から，上皮性の癌が疑われ，低分化扁平上皮癌や移行上皮癌の所見である (Fig. 3A 黒枠内拡大).

た. 経胸壁心エコーでは疮贅の所見や右左シャント の存在は認めなかったが, 感染性脳動脈瘤や腫瘍性 脳動脈瘤を疑い開頭動脈瘤トラッピング術ならびに 切除術を施行した。術中所見において, 瘤は暗褐色 であり血腫に連続した仮性瘤の形状であった。病理 検査 (Fig. 3A，B)にて動脈瘤壁に異型細胞の浸潤増殖 を認め腫瘍性動脈瘤と診断された。腫瘍細胞の結合 様式から低分化の扁平上皮癌や移行上皮癌が疑われ， 尿管癌の転移として矛盾しない所見であった，術後 は，前頭頂動脈のトラッピングに伴う脳梗塞を発症 せず，神経学的な悪化も認めず順調に経過した，再 度, 回復期リハビリテーション病棟に転床し治療を 継続した.

\section{考察}

腫瘍性脳動脈瘤は稀であり，心臟粘液腫や絨毛癌 からの転移による動脈瘤の報告が数十例報告されて いる1-13)。また，脳への転移率が高いことを反映し てか肺癌の転移に伴う腫瘍性脳動脈瘤も5 例報告さ れている14-18)。しかし，我々が涉猟しえた範囲では 尿管癌からの腫瘍性動脈瘤発症の報告例はなかった。

動脈瘤の発生は, 中大脳動脈の末梢に多いとされ ている3,6,11)。また，囊状動脈瘤は少なく紡錐状の動 脈瘤を形成することが多い6)，本例に於いても同様 の所見であった。動脈瘤の好発部位，形状には発症
機序が関わっていると考えられる．現在では二つの 発症機序が提唱されている ${ }^{1,2)}$ ，一つは血管障害説で あり，腫瘍細胞が末梢血管を塞栓したことにより血 管壁に障害を与え, 再開通とともに血行力学的に偽 性動脈瘤を形成するというものである ${ }^{9,12)}$ 。他方は 腫瘍浸潤説であり，腫瘍が直接的に血管内膜に浸潤 し，内膜や内弾性板を破壞して動脈瘤を形成すると いうものである7)，本例では，血管壁への腫瘍細胞の 浸潤を認め, 広範に内弾性板の破壊を認めたことか ら後者が原因であったと推測される。

腫瘍性動脈瘤の治療法, 治療時期に関しては, 定 石はない. 早期の開頭術を推奨する意見もあれば5), 定期的に動脈瘤の増大がないことを確認することで 保存的な加療も可能だとの意見もある ${ }^{10)}$. 本例では 1 力月の経過にて動脈瘤が発生し，破裂したために開 頭術を余儀なくされた。術中の所見でも動脈瘤壁は 極めて脆弱であり，放置していた場合の再出血率は 高いと判断した，動脈瘤の発生経過を追った報告は 少ないが $5,9,13,14)$, 数力月の経過で生じることが多い ようである，急速に増大する動脈瘤に対しては，積 極的な外科治療が必要と考えられる．Roeltgen らは 動脈瘤の自然歴を，増大し続け破裂するもの，増大 が停止し安定して自然消退するもの, 化学療法など により消退するものの三つに大別している，化学療 法の施行により動脈瘤が消退した報告もあるため4), 
未破裂例に関しては慎重な治療方針の決定が望まれ る.

腫瘍性動脈瘤は多発例の報告がされている ${ }^{1,8,10)}$. 本例に於いても先行した右前頭葉の皮質下出血に腫 瘍が関与した可能性がある。〈も膜下出血時に施行 した脳血管撮影では，右前頭葉皮質下出血部位には 動脈瘤は同定できなかったが，脳血管撮影にて同定 できない微小動脈瘤などの関与も考えられる，本例 は，インフォームドコンセントが図れず化学療法に よる原発巣のコントロールが困難であった，そのた め, 今後の動脈瘤の再発の可能性も憂慮される。明 らかなエビデンスはないが, 全脳照射による再発予 防なども検討してゆく必要があると考えられる.

\section{結語}

尿管癌の転移に伴う腫瘍性動脈瘤破裂の 1 例を報 告した．担癌状態の患者に生じた動脈瘤に於いては, 腫瘍性動脈瘤の可能性を考慮して治療にのぞむ必要 があると考えられた。

\section{参考文献}

1) Chang IB, Cho BM, Park SH, et al: Metastatic choriocarcinoma with multiple neoplastic intracranial microaneurysms: case report. J Neurosurg 108: 1014-1017, 2008 [Medline] [CrossRef]

2) Furuya K, Sasaki T, Yoshimoto Y, et al: Histologically verified cerebral aneurysm formation secondary to embolism from cardiac myxoma. Case report. J Neurosurg 83: 170-173, 1995 [Medline] [CrossRef]

3) Giannakopoulos G, Nair S, Snider C, et al: Implications for the pathogenesis of aneurysm formation: metastatic choriocarcinoma with spontaneous splenic rupture. Case report and a review. Surg Neurol 38: 236-240, 1992 [Medline] [CrossRef]

4) Hove B, Andersen BB, Christiansen TM: Intracranial oncotic aneurysms from choriocarcinoma. Case report and review of the literature. Neuroradiology 32: 526-528, 1990 [Medline] [CrossRef]

5）古明地孝宏，五十嵐幸治，滝上真良ら：脳血栓で発 症し，脳動脈瘤の形成及びくも膜下出血をきたした choriocarcinoma の 1 例. Neurol Surg 24: 463-467, 1996
6）森健太郎，三科秀人，下地武義ら：絨毛上皮腫の血 管内転移により発生した破裂脳動脈瘤の 1 例. Neurol Med Chir (Tokyo) 30: 858-862, 1990

7) New PF, Price DL, Carter B: Cerebral angiography in cardiac myxoma. Correlation of angiographic and histopathological findings. Radiology 96: 335-345, 1970 [Medline]

8) Nucifora PG, Dillon WP: MR diagnosis of myxomatous aneurysms: report of two cases. AJNR Am J Neuroradiol 22: 1349-1352, 2001 [Medline]

9) Roeltgen DP, Weimer GR, Patterson LF: Delayed neurologic complications of left atrial myxoma. Neurology 31 8-13, 1981 [Medline]

10) Ryou KS, Lee SH, Park SH, et al: Multiple fusiform myxomatous cerebral aneurysms in a patient with Carney complex. J Neurosurg 109: 318-320, 2008 [Medline] [CrossRef]

11) Sabolek M, Bachus-Banaschak K, Bachus R, et al: Multiple cerebral aneurysms as delayed complication of left cardiac myxoma: a case report and review. Acta Neurol Scand 111: 345-350, 2005 [Medline] [CrossRef]

12) Stoane L, Allen JH Jr, Collins HA: Radiologic observations in cerebral embolization from left heart myxomas. Radiology 87: 262-266, 1966 [Medline]

13) Suzuki T, Nagai R, Yamazaki $T$, et al: Rapid growth of intracranial aneurysms secondary to cardiac myxoma. Neurology 44: 570-571, 1994 [Medline]

14) Gliemroth J, Nowak G, Kehler U, et al: Neoplastic cerebral aneurysm from metastatic lung adenocarcinoma associated with cerebral thrombosis and recurrent subarachnoid haemorrhage. J Neurol Neurosurg Psychiatry 66: 246-247, 1999 [Medline] [CrossRef]

15) Ho KL: Neoplastic aneurysm and intracranial hemorrhage. Cancer 50: 2935-2940, 1982 [Medline] [CrossRef]

16) Kochi N, Tani E, Yokota M, et al: Neoplastic cerebral aneurysm from lung cancer. Case report. J Neurosurg 60 : 640-643, 1984 [Medline] [CrossRef]

17) Murata J, Sawamura Y, Takahashi A, et al: Intracerebral hemorrhage caused by a neoplastic aneurysm from smallcell lung carcinoma: case report. Neurosurgery 32: 124 126, 1993 [Medline] [CrossRef]

18) Nomura R, Yoshida D, Kim K, et al: Intracerebral hemorrhage caused by a neoplastic aneurysm from pleomorphic lung carcinoma. Neurol Med Chir (Tokyo) 49: 33-36, 2009 [Medline] [CrossRef] 


\title{
Abstract \\ Subarachnoid hemorrhage caused by a neoplastic aneurysm from a urotherial carcinoma
}

\author{
Tadashige Kano, M.D., ${ }^{1)}$ Tomo Horikoshi, M.D., ${ }^{2)}$ Takekazu Akiyama, M.D., ${ }^{3)}$ \\ Kazunori Akaji, M.D., Ph.D., ${ }^{1)}$ Yoshio Tanizaki, M.D., Ph.D., ${ }^{1)}$ Nobuhide Masawa, M.D., Ph.D., ${ }^{4)}$ \\ and Ban Mihara, M.D., Ph.D.5) \\ 1) Department of Neurosurgery, Mihara Memorial Hospital \\ 2) Department of Stroke, Mihara Memorial Hospital \\ 3) Department of Neurosurgery, Akiyama Hospital of Neurosurgery and Internal Medicine \\ 4) Department of Anatomic and Diagnostic Pathology, Dokkyo Medical University \\ 5) Department of Neurology, Mihara Memorial Hospital
}

An 86 year-old man was admitted to our hospital with sudden left paralysis. He had received no medical treatment though the ureteral carcinoma was pointed out as in the past. CT scan demonstrated subcortical hemorrhage in the right frontal lobe. MRI demonstrated no vascular abnormality. He was treated conservatively and moved to rehabilitation ward. He complained of a sudden headache on the 31st day of hospitalization. Subarachnoid hemorrhage was found in the left convexity area by CT scan and a de novo fusiform aneurysm was discovered at the peripheral branch of middle cerebral artery by MRA and angiography. Vascular trapping and resection of aneurysm was performed immediately. Postoperative, the pathological diagnosis was a neoplastic aneurysm. Atypical cells had invaded the aneurismal wall. After the operation, any cerebral infarction according to the vascular trapping did not develop. In the treatment of the patient with carcinoma, it is necessary to note that the formation and the rupture of a cerebral aneurysm will be caused in a short term.

Key words: neoplastic aneurysm, subarachnoid hemorrhage, urotherial carcinoma

(Jpn J Stroke 34: 29-33, 2012) 